\title{
FRACTIONATION OF Pinus radiata WOOD BY COMBINATION OF STEAM EXPLOSION AND ORGANOSOLV DELIGNIFICATION
}

\author{
Camila María Imlauer-Vedoya ${ }^{1, \star}$, Priscila Vergara-Alarcón ${ }^{2}$, María Cristina Area $^{3}$ Esteban Revilla \\ Fernando Esteban Felissia ${ }^{5}$, Juan Carlos Villar ${ }^{6}$
}

\begin{abstract}
This work proposes a sequential combination of steam explosion and organosolv delignification for Pinus radiata fractionation. An efficient pretreatment to fully optimize the use of lignocellulosic materials is the key to make a biorefinery profitable, especially for softwoods, known to be more recalcitrant than other lignocellulosic raw materials. Steam explosion has a dual effect on biomass as morphological and chemical changes are introduced. A delignifying stage has been stated to be necessary in order to ease hydrolytic enzymes accessibility to cellulose while avoiding non-productive bonds with the lignin present. Three steam explosion conditions were tested $\left(170^{\circ} \mathrm{C}, 5 \mathrm{~min} ; 180^{\circ} \mathrm{C}, 10 \mathrm{~min} ; 170^{\circ} \mathrm{C}, 5+5 \mathrm{~min}\right)$ followed by an organosolv delignification stage, carried out at two different conditions $\left(170^{\circ} \mathrm{C}, 60 \mathrm{~min} ; 170^{\circ} \mathrm{C}, 90 \mathrm{~min}\right)$. All treatment yields, delignification extent, and hydrolysis yields were determined to evaluate each stage. The steam explosion treatment did not produce high delignification extent. Maximum global delignification (50,4\%) was achieved when combining the two-cycle steam explosion with the most severe post-treatment condition tested. Enzymatic hydrolysis of the cellulosic residue improved after organosolv delignification; however, hydrolysis yields did not exceed $35 \%$. The chemical changes undergone by softwood lignins are presumably responsible for the low digestibility.
\end{abstract}

Keywords: Biomass, enzymatic hydrolysis, lignins, pretreatment, radiata pine.

\section{INTRODUCTION}

The environmental degradation due to greenhouse gas emissions, the increasing energy demand and the progressive depletion of fossils fuels have strengthened the interest in alternative, renewable resources to meet society basic needs of products and services (Alvira et al. 2010). Second generation biorefineries are a promising alternative to the first generation based on sugar plants or cereals. A forest biorefinery is a facility that can generate fuels, energy, and chemical products from lignocellulosic biomass from the primary processing of wood (e.g. sawdust).

\footnotetext{
${ }^{1}$ Tesista doctoral en el Programa de Celulosa y Papel, Instituto de Materiales de Misiones, IMAM (UNaM-CONICET), Misiones, Argentina.

${ }^{2}$ Tesista doctoral en el Centro de Investigación Forestales Instituto Nacional de Investigación y Tecnología Agraria y Alimentaria (INIA-CIFOR), Madrid, España.

${ }^{3}$ Directora en el Programa de Celulosa y Papel, Instituto de Materiales de Misiones, IMAM (UNaM-CONICET). Investigadora del CONICET, Misiones, Argentina.

${ }^{4}$ Técnico de I+D+I en el Departamento Productos Forestales, Centro de Investigación Forestales Instituto Nacional de Investigación y Tecnología Agraria y Alimentaria (INIA-CIFOR), Madrid, España.

${ }_{5}^{5}$ Docente-Investigador. Profesor Adjunto en la Facultad de Ciencias Exactas Químicas y Naturales, UNaM. Jefe de Laboratorio del Programa de Celulosa y Papel, Instituto de Materiales de Misiones, IMAM (UNaM-CONICET), Misiones, Argentina.

${ }^{6}$ Senior Researcher en el Departamento Productos Forestales, Centro de Investigación Forestales Instituto Nacional de Investigación y Tecnología Agraria y Alimentaria (INIA-CIFOR), Madrid, España.

•Corresponding author: camila.imlauer@gmail.com
}

Received: 07.08.2017 Accepted: 05.03.2019 
However, while lignocellulosic biomass can be used as raw material for producing a wide variety of high valued products, its processing cost must compete with those manufactured from petroleum. The optimal use of lignocellulosic biomass is of paramount importance to make it profitable in the context of a biorefinery (Area and Vallejos 2012). Identifying economically feasible and technically viable strategies for softwood fractionation represents a huge challenge since softwoods are known to be more recalcitrant than hardwoods and other lignocellulosic raw materials.

Pretreatment of lignocellulosic biomass is conducted to improve the lignocellulose accessibility and subsequent enzymatic hydrolysis by removing hemicelluloses and/or lignin, increasing porosity and disrupting the crystalline structure of cellulose (Chiaramonti et al. 2012). There are numerous physical, chemical, physicochemical and biological pretreatments to accomplish the fractionation of forest-industrial wastes into their main components. The type and severity of the selected method are assessed as a function of biomass nature and chemical compositions, involving cost, carbohydrates recovery, and uses of the obtained material (Maity 2015). The pretreatment has been shown to be a critical stage in cellulosic ethanol production, and its impact on the process as a whole is especially highlighted when substrates such as softwoods are used (Galbe and Zacchi 2012). For any pretreatment, the energy/cost involved must not be greater than the energy/ benefit obtained from the biomass. Therefore, many strategies have been studied to achieve proper softwood fractionation, including alkaline pulping, steam explosion, organosolv treatment with different solvents, and oxygen delignification, among others (Stoffel et al. 2014, Imlauer et al. 2014, Ewanick et al. 2007).

Steam explosion has been classified as a physicochemical pretreatment, as it introduces morphological and chemical variations of the lignocellulosic biomass like the breakdown of the lignocellulosic structure, the hemicelluloses hydrolysis, and the depolymerization of lignin (Singh et al. 2014). During the steam explosion process, the biomass is heated with high pressure saturated steam $\left(160-180^{\circ} \mathrm{C}\right)$ for relatively short periods, followed by a sudden decompression. This pretreatment has a series of advantages: low environmental impact and energy consumption, limited capital requirements and low chemical loads, among others (Wang et al. 2015). Moreover, it has proven to be an effective pretreatment for a wide range of biomass feedstock, though its efficiency is lower for softwoods (Sun and Cheng 2002, Singh et al. 2015). Acid catalyst addition, usually $\mathrm{H}_{2} \mathrm{SO}_{4}$ or $\mathrm{SO}_{2}$, is required as they allow shortening the residence time and decreasing the temperature of the treatment (Brodeur et al. 2011).

The amount of lignin present in pretreated softwood has been reported to play a crucial role during enzymatic hydrolysis (Berlin et al. 2006, Chandra et al. 2009). Therefore, a delignification stage is required to enhance the hydrolysis of the cellulose rich fraction obtained after SE. In organosolv pulping, delignification of the biomass takes place using an organic solvent or an organic solvent/water mixture. On the basis of a biorefinery concept, organosolv pulping has been evaluated as a potential pretreatment method for lignocellulosic biomass conversion into valuable products (Bozell et al. 2011). The main drawbacks with the use of alcohols are the high pressures generated during the treatment and the cost associated with the safety measures required for their manipulation (Oliet et al. 2002). In particular, methanol and ethanol are the two most frequently used solvents in organosolv pulping (Zhao et al. 2009). Both low boiling point alcohols improve the cooking liquor penetration into the structure of wood, resulting in a uniform and increased delignification. In addition, they prevent lignin from condensing (Muurinen 2000). Organosolv pretreatment with ethanol has been assessed using softwoods as raw material. Some studies have been carried out to achieve desirable enzymatic hydrolysis yields from softwood material treated with alcohols under several conditions. Moreover, several catalysts have been tested for organosolv pretreatment of softwoods to enhance the hydrolysis yields (Park et al. 2010).

In the present work, a sequential combination of steam explosion and organosolv pulping is proposed to evaluate steam explosion impact on the enhancement of Pinus radiata delignification and enzymatic hydrolysis to obtain second-generation bioethanol.

\section{Experimental}

\section{Raw material}

P. radiata wood was chipped, milled and screened to obtain a uniform size (less than one inch long), air dried and preserved in polyethylene bags at $25^{\circ} \mathrm{C}$ to avoid any stratification of the moisture content of the sample. 


\section{Steam explosion}

Non-catalyzed steam explosion conditions were selected to evaluate the impact of this pretreatment on the delignification step and further enzymatic hydrolysis. The steam explosion was performed in a $26 \mathrm{~L}$ stainless steel reactor, connected to a blowing tank into which chips were discharged rapidly to atmospheric pressure after the residence time was up. The reactor is also equipped with electro-valves for steam admission, and a ball valve of discharge. Before the steam explosion, chips were immersed in water at $23^{\circ} \mathrm{C}$ for $24 \mathrm{~h}$.

In the experiments, $2000 \mathrm{~g}$ of chips were treated with saturated steam at 170 and $180^{\circ} \mathrm{C}$, in one or two steam explosion cycles. The residence time in the one-cycle experiments was 5 or $10 \mathrm{~min}$, and in the two-cycle experiments, each cycle lasted $5 \mathrm{~min}$. The so called severity factor, an empirical parameter, defines the severity of steam explosion in terms of the combined effect of temperature and residence time (Overend and Chornet 1987). The severities of each experiment were calculated according to Equation 1 and are shown in Table 1.

$$
R_{o}=t e^{\frac{T-T_{r e f}}{14,75}}
$$

Where $\mathrm{R}_{0}$ is the severity factor, $\mathrm{t}$ is the retention time in minutes, $\mathrm{T}_{\text {ref }}$ is the reference temperature $\left(100^{\circ} \mathrm{C}\right)$ and $\mathrm{T}$ is the temperature of the treatment.

Table 1: Main parameters in steam explosion experiments.

\begin{tabular}{|c|c|c|c|c|c|}
\hline Experiment & \multicolumn{2}{|c|}{ Temperature $\left({ }^{\circ} \mathrm{C}\right)$} & \multicolumn{2}{|c|}{ Residence time (min) } & $\log R_{0}$ \\
\hline 1 & \multicolumn{2}{|c|}{170} & \multicolumn{2}{|c|}{5} & 2,76 \\
\hline 2 & \multicolumn{2}{|c|}{180} & \multicolumn{2}{|c|}{10} & 3,35 \\
\hline 3 & 170 & 170 & 5 & 5 & 3,06 \\
\hline
\end{tabular}

*The severity factor for the two-cycle experiment was calculated according to the criteria used in previous studies (Martín-Sampedro et al. 2012, Cotana et al. 2014).

\section{Organosolv delignification (EW)}

After the steam explosion stage, an organosolv posttreatment with ethanol (EW) was performed. The impact of the steam explosion on the delignification stage was evaluated by subjecting both the non-exploded material (as a control) and the steam explosion solid fraction (exploded material) to the organosolv treatment. It was carried out in four stainless steel pressurized 1-liter reactors (two of them filled with non-exploded material and the other two filled with exploded material). They were placed in a 25 L rotatory pressurized vessel that contained hot water for indirect heating. The rotatory vessel had a jacket-type electrical heater controlled by a computer to set the cooking temperature. Each reactor was filled with $100 \mathrm{~g}$ of dry material and cooking liquor which consisted of a $35 / 65 \%(\mathrm{v} / \mathrm{v})$ ethanol/water mixture containing sulfuric acid as catalyst $(0,9 \%$ $\mathrm{w} / \mathrm{w}$ dry wood). The liquor to wood ratio inside the reactor was $10: 1 \mathrm{~L} / \mathrm{kg}$ and the heating time to maximum temperature was $60 \mathrm{~min}$. All experiments were performed at a maximum temperature of $170^{\circ} \mathrm{C}$, during 60 and $90 \mathrm{~min}$ in order to evaluate the influence of steam explosion on the organosolv treatment at different degrees of delignification. For all experiments the heating time was $40 \mathrm{~min}$ and the cooling time was about $60 \mathrm{~min}$.

\section{Enzymatic hydrolysis (EH)}

The solid fractions resulting from the steam explosion, the control EW delignification, and the steam explosion plus ethanol:water delignification sequence were subjected to enzymatic hydrolysis (EH). The EH of the pretreated materials was carried out at $10 \%(\mathrm{w} / \mathrm{w})$ consistency and performed by a cellulolytic complex 
(Celluclast 1,5L), supplemented with $\beta$-glucosidase (Novozym 188). The enzyme doses were 15 FPU of Celluclast 1,5L and $15 \mathrm{IU}$ of $\beta$-glucosidase per gram of dry sample. Enzymatic hydrolysis was performed in a thermostatic rotary shaker at $50^{\circ} \mathrm{C}$ and $150 \mathrm{rpm}$, using $0,05 \mathrm{M}$ sodium citrate buffer $(\mathrm{pH} 4,8)$. Samples were taken after $72 \mathrm{~h}$ of incubation and the content of sugar released was analyzed by HPLC, as explained below. The hydrolysis yield was calculated according to Equation 2.

$$
\text { Hydrolysis Yield }(\% \text { odm })=\left[\frac{\left(\frac{\text { Glucose }(g)}{\text { Dry Matter }(g)}\right) \text { Pretreatment Yield }}{\text { Raw Material Glocose Content }(g)}\right] \times 100
$$

\section{Biomass characterization}

The chemical composition of the $P$. radiata chips and the solid fractions obtained after the steam explosion and the organosolv delignification were determined by following the NREL/TP-510-42618 standards. The extractives were determined as the soluble material after Soxhlet extraction with ethanol. The extractive-free samples were acid hydrolyzed, and the carbohydrate composition was analyzed on the hydrolyzates by HPLC (Agilent Technologies 1260) fitted with a refractive index detector and an Aminex HPX-87H column operated at $50^{\circ} \mathrm{C}$ with $0,6 \mathrm{~mL} \mathrm{~min}^{-1}$ of an aqueous mobile phase containing 5 $\mathrm{mmol} / \mathrm{L}$ of $\mathrm{H}_{2} \mathrm{SO}_{4}$. The solid residue of the acid hydrolysis was considered as the acid insoluble lignin.

\section{RESULTS AND DISCUSSION}

The chemical composition of $P$. radiata used as raw material is summarized in Table 2.

Table 2: Pinus radiata chemical composition.

\begin{tabular}{|l|c|}
\hline \multicolumn{1}{|c|}{ Composition } & Percentage (dry basis) \\
\hline Ash (\%) & 0,24 \\
\hline Extractives (\%) & 2,56 \\
\hline Acid-insoluble Lignin (\%) & 29,14 \\
\hline Glucan & 40,70 \\
\hline Xylan, Arabinan, Mannan, and Galactan & 21,78 \\
\hline Acetyl groups & 0,56 \\
\hline
\end{tabular}

Results of SE and EW delignification are shown in Table 3. 
Table 3: Steam Explosion and Ethanol-Water delignification of $P$. radiata chips.

\begin{tabular}{|c|c|c|c|c|c|c|c|c|}
\hline \multicolumn{2}{|c|}{ SE } & \multirow{2}{*}{$\begin{array}{c}\text { EW } \\
\text { Conditions } \\
\left({ }^{\circ} \mathrm{C} ; \text { min }\right)\end{array}$} & \multicolumn{2}{|c|}{ Steam Explosion (SE) } & \multicolumn{2}{|c|}{ Ethanol-Water (EW) } & \multicolumn{2}{|r|}{ Global } \\
\hline $\begin{array}{l}\text { Conditions } \\
\left({ }^{\circ} \mathrm{C} ; \text { min }\right)\end{array}$ & $\begin{array}{c}\text { Severity } \\
\log \text { Ro }\end{array}$ & & $\begin{array}{c}\text { Yield } \\
(\%)\end{array}$ & $\begin{array}{c}\text { Delignification } \\
(\%)\end{array}$ & $\begin{array}{l}\text { Yield } \\
(\%)\end{array}$ & $\begin{array}{c}\text { Delignification } \\
(\%)\end{array}$ & $\begin{array}{c}\text { Yield } \\
(\%)\end{array}$ & $\begin{array}{c}\text { Delignification } \\
(\%)\end{array}$ \\
\hline-- & -- & $170 ; 60$ & -- & -- & 70,5 & 18,8 & 70,5 & 18,8 \\
\hline $170 ; 5$ & 2,76 & & 93,3 & 5,2 & 70,6 & 19,7 & 65,9 & 24,9 \\
\hline $180 ; 10$ & 3,35 & & 84,6 & 12,7 & 74,7 & 16,0 & 63,2 & 28,7 \\
\hline $170 ; 5+5$ & 3,05 & & 76,8 & 24,0 & 75,0 & 16,7 & 57,6 & 40,7 \\
\hline-- & & $170 ; 90$ & - & -- & 70,4 & 16,8 & 70,4 & 16,8 \\
\hline $170 ; 5$ & 2,76 & & 93,3 & 5,2 & 72,8 & 18,4 & 67,9 & 23,6 \\
\hline $180 ; 10$ & 3,35 & & 84,6 & 12,7 & 73,6 & 19,5 & 62,3 & 32,2 \\
\hline $170 ; 5+5$ & 3,05 & & 76,8 & 24,0 & 75,2 & 30,7 & 57,8 & 54,7 \\
\hline
\end{tabular}

Steam explosion decreased as the severity factor increased due to the solubilization of the material, varying from $93,3 \%$ to $76,8 \%$ (Table 3 ). These values are higher than those obtained by other authors in catalyzed steam explosion of softwoods (Cotana et al. 2014, Stoffel 2016).

The solid fraction obtained as a result of the steam explosion pretreatment consisted mainly of cellulose and lignin. The content of hemicelluloses significantly decreased because of their selective removal during the pretreatment. SE delignification was poor and ranged from $5,2 \%$ to $24 \%$ for all experiments, but the percentage of lignin in the fibrous solid increased due to the extraction of hemicelluloses. The highest delignification was obtained with the two-cycle treatment. Although steam explosion does not significantly remove lignin, this process has proven to disrupt the cell wall, weakening the lignin-carbohydrate complex (Wang et al. 2015). There is also evidence of lignin redistribution in dense particles within the cell wall, modifying the porosity of the material and the enzyme accessibility (Donaldson et al. 1988). Moreover, studies on chemical changes of steam-exploded lignins have revealed depolymerization and repolymerization reactions as a consequence of the acidity of the medium (Li et al. 2007, Laureano-Perez et al. 2005, Trajano et al. 2013, Shevchenko et al. 1999). There is an increase in the delignification extent as the SE severity increases, up to a point where condensation reactions prevail. Both physical and chemical changes of the lignin present in the steam exploded material would have a direct impact on downstream processes, but the influence of the SE severity on delignification depends on the type of post-treatment (Kumar et al. 2011).

Studies conducted on the chemistry of the organosolv process have suggested that $\alpha$-ether linkage cleavage is the most important reaction in lignin breakdown, especially in acidic systems (Aziz and Goyal 1993). Control EW experiments (non-exploded materials) showed poor delignification values, in contrast with previous studies of organosolv pulping of softwoods species, including $P$. radiata (Donaldson et al. 1988, Araque et al. 2008, Pan et al. 2008). Lignin removal in the EW stage decreased with increasing time, from $18,8 \%$ (60-minute treatment) to $16,8 \%$ (90-minute treatment). Since during acidic organosolv pulping a reactive intermediate is formed as a consequence of $\alpha$-ether cleavage of lignin (McDonough 1992), this result may suggest that lignin undergoes a series of condensation reactions when the duration of the treatment is extended under the conditions tested. These results agree with another study in which high severity conditions in acidic organosolv treatment (acetone: water 50:50\% (v/v), sulfuric acid $0,9 \% \mathrm{w} / \mathrm{w}, 195^{\circ} \mathrm{C}, 40 \mathrm{~min}$ ) produced the lowest delignification (20,6\%) (Ewanick et al. 2007).

Delignification in the shortest organosolv treatment decreased with the severity of the SE, from $19,8 \%$ to $16 \%$. Conversely, the highest delignification was achieved for the material from the two-cycle SE in the case of the 90-minute organosolv treatment. However, the global delignification always increased when severity increased, but the highest delignification was obtained when combining two SE cycles. SE performed at the lowest tested pressure but in two cycles showed between 30 and $40 \%$ higher delignification percentages than the one cycle experiments. The combination of two SE cycles, in comparison with only one cycle of equivalent duration clearly improves delignification and yields a solid with a global delignification of about $55 \%$. Delignification time did not have a significant effect on yield.

Enzymatic hydrolysis was performed to evaluate the effect of the steam explosion on enhancing the accessibility of enzymes to the cellulose-rich material. Samples were taken after $72 \mathrm{~h}$ of incubation and the conversion of cellulose to glucose (hydrolysis yield) was determined. Steam exploded materials and the substrates obtained from the combination of SE and EW pulping were subjected to this procedure. Hydrolysis yields are shown in Figure 1. 


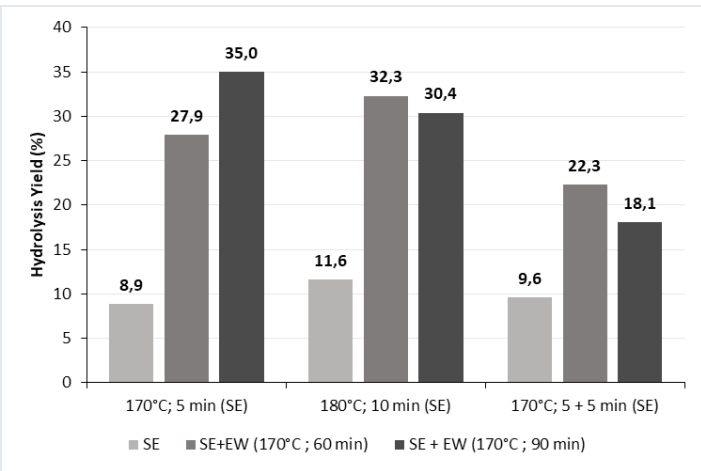

Figure 1: Enzymatic hydrolysis of the cellulose-rich residues vs SE conditions.

The hydrolysis yields of the steam exploded materials from all SE conditions ranged between $8,9 \%$ and $11,6 \%$ (corresponding to the single 10-minute cycle). The high lignin content of these materials could explain the poor hydrolysis yields, as it has been proven that lignin form non-productive bonds with enzymes (Kumar et al. 2012, Rahikainen et al. 2013). $\mathrm{H}_{2} \mathrm{SO}_{4}$-catalyzed SE of pine sawdust achieved hydrolysis yields of about $24 \%$ under severe conditions $\left(200^{\circ} \mathrm{C}, 5 \mathrm{~min}\right.$ and $\left.3 \% \mathrm{w} / \mathrm{w} \mathrm{H}_{2} \mathrm{SO}_{4}\right)$ (Stoffel et al. 2017). However, these results are significantly lower than those of other authors who obtained cellulose to glucose conversions of $77 \%$ using a high severity $\mathrm{SO}_{2}$-catalyzed $\left.\mathrm{SE}\left(215^{\circ} \mathrm{C}, 5 \mathrm{~min}, 4,5 \% \mathrm{w} / \mathrm{w} \mathrm{SO}\right)_{2}\right)$ with beetle-killed lodgepole pine chips (Ewanick et al. 2007). Presumably, the combination of high severity and the addition of $\mathrm{SO}_{2}$ produced further disruption of the lignocellulosic matrix and improved hemicellulose removal. Similar results were obtained by other researchers working with higher severities than those used in the present work and/or with acid catalyst (Söderström et al. 2003, Cotana et al. 2014, Asada et al. 2015).

The two-cycle steam-exploded material, which experienced the higher level of delignification, did not produce the most hydrolysable residue, what could be due to the removal of the most accessible cellulose.

Many studies carried out on softwood samples have suggested that a further treatment of the cellulose rich fraction is required to achieve good hydrolysis yields (Kumar et al. 2010, Kumar et al. 2011, Pan et al. 2004, Kumar et al. 2012), whereas others have highlighted that readily hydrolyzed material is obtained at the expense of high sugar loss (Wu et al. 1999, Söderström et al. 2003, Yang et al. 2002).

EW delignification significantly increased the hydrolysis yield of the steam exploded materials, even though the combination of both treatments did not produce an easily hydrolyzable solid. Hydrolysis yields did not exceed $35 \%$ and, once again, higher delignification did not necessarily correspond with higher $\mathrm{EH}$ yield. These results are considerably inferior to those obtained for Douglas-fir chips subjected to the $\mathrm{SO}_{2}$ catalyzed steam explosion followed by an alkali-oxygen delignification stage (90\% EH yield) (Pan et al. 2004). This sharp difference could be due to a more extensive delignification of the steam pretreated material and the fact that an inverse non-linear correlation between lignin content and hydrolysis susceptibility has been previously observed (Pan et al. 2005, Kruyeniski et al. 2016). The addition of an SE pretreatment has a positive effect on the EH when comparing the results herein with those obtained after a single organosolv treatment of Pinus taeda and Pinus elliottii sawdust mix (below 10\%) (Kruyeniski et al. 2015). The disruption of the lignocellulosic structure that takes place during SE may be the reason why higher EH yields are attained with this work strategy.

Results reported in the literature of EH yields after SE treatments applied to different raw materials are shown in Table 4. 
Table 4: Hydrolysis yields of different raw materials subjected to steam explosion pretreatment.

\begin{tabular}{|c|c|c|c|c|c|}
\hline \multirow{2}{*}{$\begin{array}{c}\text { Raw } \\
\text { Material }\end{array}$} & \multirow{2}{*}{$\begin{array}{c}\text { Steam } \\
\text { Explosion } \\
\text { Conditions }\end{array}$} & \multirow[t]{2}{*}{ Post-treatment } & \multicolumn{2}{|c|}{ Enzymatic Hydrolysis } & \multirow[t]{2}{*}{ Ref } \\
\hline & & & Conditions & $\begin{array}{c}\text { Glucose } \\
\text { conversion }(\%) \\
\end{array}$ & \\
\hline $\begin{array}{l}\text { Wheat } \\
\text { Straw }\end{array}$ & $\begin{array}{c}220^{\circ} \mathrm{C} \\
3 \mathrm{~min} \\
\text { Autohydroly } \\
\text { sis } \\
\end{array}$ & No & $\begin{array}{c}25 \mathrm{FPU} / \mathrm{g} \text { substrate; } \\
50^{\circ} \mathrm{C} ; \mathrm{pH}=4,8 ; 160 \\
\mathrm{rpm} ; 60 \mathrm{~h} ; 2 \% \mathrm{w} / \mathrm{v} \\
\text { consistency }\end{array}$ & $86,42 \%$ & 1 \\
\hline $\begin{array}{l}\text { Native } \\
\text { sugarcane } \\
\text { bagasse } \\
\text { Ethanol } \\
\text { extracted } \\
\text { sugarcane } \\
\text { bagasse }\end{array}$ & $\begin{array}{c}195^{\circ} \mathrm{C} \\
7,5 \mathrm{~min} \\
\text { Autohydroly } \\
\text { sis/ } \\
\mathrm{H}_{2} \mathrm{SO}_{4} \text { and } \\
\mathrm{H}_{3} \mathrm{PO}_{4} \\
9,5 \mathrm{mg} / \mathrm{g} \\
\text { total solid }\end{array}$ & No & $\begin{array}{l}\text { 8,4 FPU/g total solid } \\
\left(\text { Cellic CTec2); } 50^{\circ} \mathrm{C}\right. \\
\text { pH=4,8; } 96 \mathrm{~h} ; 12 \% \\
\text { w/w consistency. }\end{array}$ & Near $100 \%$ & 2 \\
\hline $\begin{array}{l}\text { Eucalyptus } \\
\text { globulus } \\
\text { chips }\end{array}$ & $\begin{array}{c}183^{\circ} \mathrm{C} \\
1^{\text {st }} \text { cycle } \\
\text { time: } 10 \mathrm{~min} \\
2^{\text {nd }} \text { cycle } \\
\text { time: } 3 \text { min } \\
\text { (fixed) } \\
\text { Autohydroly } \\
\text { sis } \\
\log \mathrm{R}_{0}=3,56\end{array}$ & No & $\begin{array}{c}\text { 1:3 ratio of cellulase } \\
\text { (20 EGU/g substrate) } \\
\text { and } \beta \text {-glucosidase; } \\
50^{\circ} \mathrm{C} ; \mathrm{pH}=4,8 ; 72 \mathrm{~h} ; \\
50 \mathrm{~g} / \mathrm{L} \text { of the pretreated } \\
\text { material. }\end{array}$ & $\begin{array}{c}\approx 14 \% \text { (non- } \\
\text { exploded chips) } \\
24,7 \% \text { (Water } \\
\text { pre-extracted } \\
\text { chips) }\end{array}$ & 3 \\
\hline $\begin{array}{l}\text { Eucalyptus } \\
\text { grandis } \\
\text { industrial } \\
\text { chips }\end{array}$ & $\begin{array}{c}200^{\circ} \mathrm{C} \\
2 \mathrm{~min} \\
\mathrm{H}_{2} \mathrm{SO}_{4}: \\
0,175 \% \mathrm{w} / \mathrm{w}\end{array}$ & No & $\begin{array}{c}25 \mathrm{FPU} / \mathrm{g} \text { substrate } \\
\text { (cellulase }+\beta- \\
\text { glucosidase) } ; 45^{\circ} \mathrm{C} ; \\
\mathrm{pH}=4,8 ; 145 \mathrm{rpm} ; 48 \mathrm{~h} ; \\
2 \% \mathrm{w} / \mathrm{v} \text { consistency. }\end{array}$ & $56,53 \%$ & 4 \\
\hline $\begin{array}{l}\text { Poplar } \\
\text { chips }\end{array}$ & $\begin{array}{c}170^{\circ} \mathrm{C} \\
15 \mathrm{~min} \\
\mathrm{SO}_{2}: 6 \% \\
\mathrm{w} / \mathrm{w}\end{array}$ & $\begin{array}{l}\text { Organosolv } \\
\text { Treatment }\end{array}$ & $\begin{array}{c}5 \mathrm{FPU} / \mathrm{g} \text { cellulose } \\
\text { (cellulase) } / 10 \mathrm{CBU} / \mathrm{g} \\
\text { cellulose }(\mathrm{b}- \\
\text { glucosidase) } ; 50^{\circ} \mathrm{C} ; \\
\mathrm{pH}=4,8 ; 150 \mathrm{rpm} ; 72 \mathrm{~h} ; \\
2 \% \mathrm{w} / \mathrm{v} \text { consistency. }\end{array}$ & More than $85 \%$ & 5 \\
\hline $\begin{array}{c}\text { Pine } \\
\text { sawdust }\end{array}$ & $\begin{array}{c}200^{\circ} \mathrm{C} \\
5 \mathrm{~min} \\
\mathrm{H}_{2} \mathrm{SO}_{4}: 3 \% \\
\mathrm{w} / \mathrm{w} \\
\mathrm{CS}=3,3\end{array}$ & $\begin{array}{l}\text { 1.Soda/AQ } \\
\text { 2.Soda/Ethanol } \\
\text { 3.Soda/Hydroge } \\
\text { n 4.Peroxide } \\
\text { Soda/Oxygen }\end{array}$ & $\begin{array}{l}20 \mathrm{FPU} / \mathrm{g} \text { glucans } \\
\text { (cellulase) } / 40 \mathrm{IU} / \mathrm{g} \\
\text { glucans }(\beta- \\
\text { glucosidase); } \\
50^{\circ} \mathrm{C} ; \mathrm{pH}=4,8 ; 150 \\
\mathrm{rpm} ; 72 \mathrm{~h} ; 2 \% \mathrm{w} / \mathrm{w} \\
\text { consistency. }\end{array}$ & $\begin{array}{l}\mathrm{SE}+1: 36,00 \% \\
\mathrm{SE}+2: 28,10 \% \\
\mathrm{SE}+3: 27,50 \% \\
\mathrm{SE}+4: 25,40 \%\end{array}$ & 6 \\
\hline $\begin{array}{c}\text { Douglas- fir } \\
\text { (Pseudotsuga } \\
\text { menziesii) } \\
\text { chips }\end{array}$ & $\begin{array}{c}190^{\circ} \mathrm{C}(\mathrm{LSP}) \\
200^{\circ} \mathrm{C} \\
(\mathrm{MSP}) \\
210^{\circ} \mathrm{C} \\
(\mathrm{HSP}) \\
5 \mathrm{~min} \\
\mathrm{SO}_{2}: 4 \% \\
\mathrm{w} / \mathrm{w}\end{array}$ & $\begin{array}{c}\text { 1.Alkaline } \\
\text { Hydrogen } \\
\text { Peroxide } \\
\text { 2.Alkali } \\
\text { Treatment } \\
\text { 3.Neutral } \\
\text { Sulfonation } \\
\text { 4.Acid Chlorite } \\
\text { Partial } \\
\text { Delignification }\end{array}$ & $\begin{array}{c}15 \mathrm{FPU} / \mathrm{g} \text { cellulose } \\
\text { (cellulase) } / 30 \mathrm{CBU} / \mathrm{g} \\
\text { cellulose }(\beta- \\
\text { glucosidase) } ; 50^{\circ} \mathrm{C} ; \\
\mathrm{pH}=4,8 ; 150 \mathrm{rpm} ; 72 \mathrm{~h} ; \\
2 \% \mathrm{w} / \mathrm{w} \text { consistency. }\end{array}$ & $\begin{array}{c}\text { HSP + No Post } \\
\text { Treatment: } \\
\text { 20,50\% } \\
\text { 1 + MSP: } 61 \% \\
\text { 2: }<10 \% \\
\text { (LSP/MSP/HSP) } \\
3 \text { + HSP: } 68 \% \\
4 \text { + HSP: } 67 \%\end{array}$ & 7 \\
\hline $\begin{array}{l}\text { Slash Pine } \\
\text { sawdust } \\
\text { preextracted } \\
\text { with dilute } \\
\text { alkali } \\
\text { (AP) }\end{array}$ & $\begin{array}{c}200^{\circ} \mathrm{C} \\
5 \mathrm{~min} \\
\mathrm{H}_{2} \mathrm{SO}_{4}: 3 \% \\
\mathrm{w} / \mathrm{w} \\
\mathrm{CS}=3,3\end{array}$ & No & $\begin{array}{l}20 \mathrm{FPU} / \mathrm{g} \text { glucans } \\
\text { (cellulase) } / 40 \mathrm{IU} / \mathrm{g} \\
\text { glucans }(\beta- \\
\text { glucosidase); } \\
50^{\circ} \mathrm{C} ; \mathrm{pH}=4,8 ; 150 \\
\mathrm{rpm} ; 72 \mathrm{~h} ; 2 \% \mathrm{w} / \mathrm{w} \\
\text { consistency. }\end{array}$ & $\begin{array}{c}3,76 \% \text { (original } \\
\text { pine sawdust) } \\
24,30 \% \text { (AP) }\end{array}$ & 8 \\
\hline
\end{tabular}

${ }^{1}$ (Cui et al. 2012), ${ }^{2}$ (Neves et al. 2016), ${ }^{3}$ (Martín-Sampedro et al. 2012), ${ }^{4}$ (Emmel et al. 2003), ${ }^{5}$ (Panagiotopoulos et al. 2013), ${ }^{6}($ Stoffel et al. 2016a), ${ }^{7}\left(\right.$ Kumar et al. 2011), ${ }^{8}$ (Stoffel et al. 2017). 
Steam explosion has proved to be a good option as pretreatment for non-woody lignocellulosic materials like wheat straw and sugarcane bagasse (Cui et al. 2012, Neves et al. 2016) (Table 4). Also, EH yield of steam exploded Eucalyptus globulus ( $\left.\log \mathrm{R}_{0}=3,56\right)$ was $24,7 \%$ (Martín-Sampedro et al. 2012) whereas in this work, Pinus radiata sawdust pretreated with similar severity $\left(\log \mathrm{R}_{0}=3,35\right)$, did not exceed $12 \%$. Moreover, acid-catalyzed steam explosion of Eucalyptus grandis chips achieved a EH yield of about 57\% (Emmel et al. 2003), twice as high as the one recorded for Slash pine sawdust obtained under similar conditions (Stoffel et al. 2017). These differences could be related to the amount and type of lignin present in softwoods (Asada et al. 2015). In a study on isolated lignins from pretreated corn stover, poplar, and lodgepole pine on the EH, Nakagame et al. (2010) found that softwood lignin has a stronger negative influence on EH than that of other sources. Also poplar chips (Table 4) proved to render a more readily hydrolysable material (over $85 \%$ cellulose to glucose conversion) (Panagiotopoulos et al. 2013) than Pinus radiata sawdust (up to 35\%), both pretreated under a similar SE severity. The addition of an acid catalyst may be suggested as an explanation for the abovementioned difference. Nevertheless, other studies on softwood did not report hydrolysis yields higher than $36 \%$ for Slash pine and 68\% for Douglas-fir (Stoffel et al. 2016a, Kumar et al. 2011). Steam explosion is one of the best processes to extract hemicelluloses from softwoods, but it can be negative for the digestibility of the remaining solid fraction, highly dependent on the quantity and quality of lignin. Stoffel et al. (2017) extracted $90 \%$ of the hemicelluloses with the steam explosion pretreatment but the hydrolysis yields of the resulting cellulosic fraction were poor $(24,3 \%)$, (Table 4). Even alkaline delignifying post-treatments (Stoffel et al. 2016a) did not prompt a significant improvement of the EH yield, in agreement with our results. The chemical and structural changes produced in lignin during the steam explosion are presumably responsible for the decrease in the ability of delignifying post-treatments (Pielhop et al. 2015). High steam explosion severities prompt lignin condensation reactions which counteract the depolymerization reactions. This applies to softwood lignins, with a high content of derivatives of guaiacyl-propane structures, which are more susceptible to condensation reactions than the syringyl-propane ones, predominant in hardwood species (McDonough 1992). Pielhop et al. (2015) concluded that repolymerization reactions, especially important in softwoods lignins, modifies lignin nanostructure in a way that significantly increases its specific surface area. Therefore, condensed lignin in substrates from autohydrolysis pretreatments represent an obstacle to EH. However, lignin removal does not necessarily correlate with the ease of hydrolysis. Lignin redistribution during steam explosion treatment, and lignin nature because of its susceptibility to depolymerization/condensation reactions and hydrophobicity, have a significant effect on downstream EH (Kumar et al. 2011), The correlation between lignin hydrophobicity and cellulases adsorption (hydrophobic interaction) has been previously suggested in the literature (Berlin et al. 2006). i.e., a higher hydrophobicity of lignin in the pretreated substrate could mean a higher interaction with cellulases (non-productive binding) and, thus, a decrease in EH yield. Compared with other pretreated lignocellulosic materials, Nakagame et al. (2010) findings suggested that isolated softwood lignins show higher hydrophobic behavior.

The literature in Table 4 shows that, even when higher hydrolysis yields may be obtained from softwood than those recorded in this work, they are only comparable to those obtained from steam exploded hardwood or nonwoody lignocellulosic materials when using high severity factors with the aid of an acid catalyst or/and a post-delignification stage, proving softwood recalcitrant nature. This work demonstrated that the sequential application of SE followed by an EW delignification for Pinus radiata sawdust did not significantly enhance the digestibility of the cellulosic residue obtained during the SE. These results agree with other authors, who noticed that softwoods subjected to autohydrolysis or acid-catalysed pretreatments exhibit a recalcitrant behavior towards downstream processes, such as delignification and enzymatic hydrolysis.

\section{CONCLUSIONS}

A sequential combination of steam explosion and organosolv post-treatment was performed to evaluate the impact of the steam explosion pretreatment on Pinus radiata delignification and subsequent digestibility.

Low delignification was recorded after the steam explosion pretreatment. Moreover, a further delignification stage (organosolv post-treatment) did not considerably remove the lignin content of the steam-exploded material, presumably due to the chemical changes underwent by softwood lignins. The maximum global delignification corresponded to materials subjected to the explosion stage in two-cycles $(54,7 \%)$.

EH yields of the materials obtained after the steam explosion and the organosolv treatment did not exceed 
$35 \%$. Though the tested strategy improved the exploded material digestibility, it did not allow to obtain a readily hydrolyzable material.

The recalcitrant nature of the tested raw material, in addition to the presumably lignin chemical modifications and redistribution within the cellulose-rich fraction after the treatments, prove to have a synergetic negative effect on the ease of hydrolysis of the resulting material.

\section{ACKNOWLEDGEMENTS}

The authors deeply acknowledge PROVALOR network (Productos de valor agregado a partir de residuos agro y forestoindustriales), CONICET (National Council of Scientific and Technical Research), UNaM (National University of Misiones), MINECO (Project CTQ 2010-17702) and the Madrid Regional Government (Project RETO PROSOST P2013-MAE2907) for the financial support.

\section{REFERENCES}

Alvira, P.; Tomás-Pejó, E.; Ballesteros, M.; Negro, M.J. 2010. Pretreatment technologies for an efficient bioethanol production process based on enzymatic hydrolysis: A review. Bioresource Technology 101(13): 4851-4861.

Araque, E.; Parra, C.; Freer, J.; Contreras, D.; Rodríguez, J.; Mendonça, R.; Baeza, J. 2008. Evaluation of organosolv pretreatment for the conversion of Pinus radiata D. Don to ethanol. Enzyme and Microbial Technology 43 (2): 214-219.

Area, M.C.; Vallejos, M.E. 2012. Biorrefinería a partir de residuos lignocelulósicos. Saarbrucken, Alemania: Editorial Académica Española.

Asada, C.; Sasaki, C.; Hirano, T.; Nakamura, Y. 2015. Chemical characteristics and enzymatic saccharification of lignocellulosic biomass treated using high-temperature saturated steam: Comparison of softwood and hardwood. Bioresource Technology 182: 245-250.

Aziz, S.; Goyal, G.C. 1993. Kinetics of delignification from mechanistic and process control point of view in solvent pulping processes. TAPPI Pulping Conference.

Berlin, A.; Balakshin, M.; Gilkes, N.; Kadla, J.; Maximenko, V.; Kubo, S.; Saddler, J. 2006. Inhibition of cellulase, xylanase and $\beta$-glucosidase activities by softwood lignin preparations. Journal of Biotechnology 125 (2): 198-209.

Bozell, J.J.; Black, S.K.; Myers, M.; Cahill, D., Miller, W.P.; Park, S. 2011. Solvent fractionation of renewable woody feedstocks: Organosolv generation of biorefinery process streams for the production of biobased chemicals. Biomass and Bioenergy 35 (10): 4197-4208.

Brodeur, G.; Yau, E.: Badal, K.; Collier, J.; Ramachandran, K.B.; Ramakrishnan, S. 2011. Chemical and Physicochemical Pretreatment of Lignocellulosic Biomass: A Review. Enzyme Research 2011. Article ID $787532.17 \mathrm{p}$.

Chandra, R.P.; Ewanick, S.M.; Chung, P.A.; Au-Yeung, K.; Del Rio, L.; Mabee, W.; Saddler, J. N. 2009. Comparison of methods to assess the enzyme accessibility and hydrolysis of pretreated lignocellulosic substrates. Biotechnology Letters 31(8): 1217-1222.

Chiaramonti, D.; Prussi, M.; Ferrero, S.; Oriani, L.; Ottonello, P.; Torre, P.; Cherchi, F. 2012. Review of pretreatment processes for lignocellulosic ethanol production, and development of an innovative method. Biomass and Bioenergy 46: 25-35.

Cotana, F.; Cavalaglio, G.; Gelosia, M.; Coccia, V.; Petrozzi, A.; Nicolini, A. 2014. Effect of double- 
step steam explosion pretreatment in bioethanol production from softwood. Applied Biochemistry and Biotechnology 174 (1): 156-167.

Cui, L.; Liu, Z.; Si, C.; Hui, L.; Kang, N.; Zhao, T. 2012. Influence of steam explosion pretreatment on the composition and structure of wheat straw. BioResources 7 (3): 4202-4213.

Donaldson, L.A.; Wong, K.K.Y.; Mackie, K.L. 1988. Ultrastructure of steam-exploded wood. Wood Science and Technology 22: 103-114.

Emmel, A.; Mathias, A.L.; Wypych, F.; Ramos, L.P. 2003. Fractionation of Eucalyptus grandis chips by dilute acid-catalysed steam explosion. Bioresource Technology 86 (2): 105-115.

Ewanick, S.M.; Bura, R.; Saddler, J.N. 2007. Acid-Catalyzed Steam Pretreatment of Lodgepole Pine and Subsequent Enzymatic Hydrolysis and Fermentation to Ethanol. Biotechnology and Bioengineering 98 (4): 737-746.

Galbe, M.; Zacchi, G. 2012. Pretreatment: The key to efficient utilization of lignocellulosic materials. Biomass and Bioenergy 46: 70-78.

Imlauer, C.M.; Kruyeniski, J.; Area, M.C.; Felissia, F.E. 2014. Fraccionamiento a la Soda-AQ de aserrín de pino para la biorefinería forestal. The VIII IberoAmerican Congress on Pulp and Paper Research. Medellín, Colombia: 26-28.

Kruyeniski, J.; Felissia, F.E.; Area, M.C. 2015. Enzymatic Hydrolysis of Pine Pretreated with Ethanol and Sodium Hydroxide. 3rd Iberoamerican Congress. 4th Latin American Congress. 2nd International Symposium on Lignocellulosic Materials. Concepción. Chile.159p.

Kruyeniski, J.; Ferreira, P.; Graça V.S.; Carvalho, M.; Felissia, F.; Area, M.C. 2016. Physical and chemical characteristics of pretreated pine sawdust and its enzymatic hydrolysis. The IX IberoAmerican Congress on Pulp and Paper Research. Helsinki, Finland.

Kumar, L.; Arantes, V.; Chandra, R.; Saddler, J. 2012. The lignin present in steam pretreated softwood binds enzymes and limits cellulose accessibility. Bioresource Technology 103: 201-208.

Kumar, L.; Chandra, R.; Chung, P.A; Saddler, J. 2010. Can the same steam pretreatment conditions be used for most softwoods to achieve good, enzymatic hydrolysis and sugar yields? Bioresource technology 101(20): 7827-7833.

Kumar, L.; Chandra, R.; Saddler, J. 2011. Influence of steam pretreatment severity on post-treatments used to enhance the enzymatic hydrolysis of pretreated softwoods at low enzyme loadings. Biotechnology and Bioengineering 108: 2300-2311.

Laureano-Perez, L.; Teymouri, F.; Alizadeh, H.; Dale, B.E. 2005. Understanding factors that limit enzymatic hydrolysis of biomass. Applied Biochemistry and Biotechnology 121-124: 1081-1099.

Li, J.; Henriksson, G.; Gellerstedt, G. 2007. Lignin depolymerization/repolymerization and its critical role for delignification of aspen wood by steam explosion. Bioresource Technology 98: 3061-3068.

Maity, S.K. 2015. Opportunities, recent trends and challenges of integrated biorefinery: Part II. Renewable and Sustainable Energy Reviews 43: 1446-1466.

Martín-Sampedro, R.; Eugenio, M.E.; García, J.C.; Lopez, F.; Villar, J.C.; Diaz, M.J. 2012. Steam explosion and enzymatic pre-treatments as an approach to improve the enzymatic hydrolysis of Eucalyptus globulus. Biomass and Bioenergy 42: 97-106.

McDonough, T. 1992. The chemistry of organosolv delignification. IPST Technical Paper Series 455: $1-17$.

Muurinen, E. 2000. Organosolv pulping. A review and distillation study related to peroxyacid pulping. Academic Dissertation. Faculty of Technology, University of Oulu. Finland. (Available online: http://herkules. oulu.fi/isbn9514256611/isbn9514256611.pdf). 
Nakagame, S.; Chandra, R.P.; Saddler, J.N. 2010. The effect of isolated lignins, obtained from a range of pretreated lignocellulosic substrates, on enzymatic hydrolysis. Biotechnology and Bioengineering 105 (5): 871-879.

Neves, P.V.; Pitarelo, A.P.; Ramos, L.P. 2016. Production of cellulosic ethanol from sugarcane bagasse by steam explosion: Effect of extractives content, acid catalysis and different fermentation technologies. Bioresource Technology 208: 184-194.

Oliet, M.; García, J.; Rodríguez, F.; Gilarrranz, M.A. 2002. Solvent effects in autocatalyzed alcoholwater pulping: Comparative study between ethanol and methanol as delignifying agents. Chemical Engineering Journal 87:157-162.

Overend, R.P.; Chornet, E. 1987. Fractionation of Lignocellulosics by Steam-Aqueous Pretreatments. Phil Trans R Soc Lond 321: 523-536.

Pan, X.; Arato, C.; Gilkes, N.; Gregg, D.; Mabee, W.; Pye, K.; Xiao, Z.; Zhang, X; Saddler, J. 2005. Biorefining of softwoods using ethanol organosolv pulping: Preliminary evaluation of process streams for manufacture of fuel-grade ethanol and co-products. Biotechnology and Bioengineering 90 (4): 473-481.

Pan, X.; Xie, D.; Yu, R.W.; Saddler, J.N. 2008. The bioconversion of mountain pine beetle-killed lodgepole pine to fuel ethanol using the organosolv process. Biotechnology and Bioengineering 101 (1): 39-48.

Pan, X.; Zhang, X.; Gregg, D.J.; Saddler, J.N. 2004. Enhanced enzymatic hydrolysis of steam-exploded Douglas fir wood by alkali-oxygen post-treatment. Applied Biochemistry and Biotechnology 113(116):11031114.

Panagiotopoulos, I.A.; Chandra, R.P.; Saddler, J.N. 2013. A two-stage pretreatment approach to maximise sugar yield and enhance reactive lignin recovery from poplar wood chips. Bioresource Technology 130: $570-577$.

Park, N.; Kim, H.; Koo, B.; Yeo, H.; Choi, I. 2010. Organosolv pretreatment with various catalysts for enhancing enzymatic hydrolysis of pitch pine (Pinus rigida). Bioresource Technology 101: 7046-7053.

Pielhop, T.; Larrazábal, G.O.; Studer, M.H.; Brethauer, S.; Seidel, C.M.; Rudolf Von Rohr, P. 2015. Lignin repolymerisation in spruce autohydrolysis pretreatment increases cellulase deactivation. Green Chem. 17: 3521-3532.

Rahikainen, J.L.; Martin-Sampedro, R.; Heikkinen, H.; Rovio, S.; Marjamaa, K.; Tamminen, T.; Rojas, O.J.; Kruus, K. 2013. Inhibitory effect of lignin during cellulose bioconversion: The effect of lignin chemistry on non-productive enzyme adsorption. Bioresource Technology 133: 270-278.

Shevchenko, S.M.; Beatson, R.P.; Saddler, J.N. 1999. The Nature of Lignin from Steam Explosion / Enzymatic Hydrolysis of Softwood. Applied Biochemistry and Biotechnology 77(79): 867-876.

Singh, J.; Suhag, M.; Dhaka, A. 2015. Augmented digestion of lignocellulose by steam explosion, acid and alkaline pretreatment methods: A review. Carbohydrate Polymers 117: 624-631.

Singh, R.; Shukla, A.; Tiwari, S.; Srivastava, M. 2014. A review on delignification of lignocellulosic biomass for enhancement of ethanol production potential. Renewable and Sustainable Energy Reviews 32: 713-728.

Söderström, J.; Pilcher, L.; Galbe, M.; Zacchi, G. 2003. Two-step steam pretreatment of softwood by dilute $\mathrm{H}_{2} \mathrm{SO}_{4}$ impregnation for ethanol production. Biomass and Bioenergy 24: 475-486.

Stoffel, R.B. 2016. Fraccionamiento de aserrín de pino destinado a una Biorrefinería Forestal. Ph.D. Thesis. Universidad Nacional de La Plata, Buenos Aires, Argentina. Available online: http://sedici.unlp.edu. ar/handle/10915/52523.

Stoffel, R.B.; Acuña, A.A.; Felissia, F.E.; Gassa, L.M.; Area, M.C. 2016a. Post treatment to enhance enzymatic hydrolysis yield of steam exploded pine sawdust. The IX IberoAmerican Congress on Pulp and Paper Research, CIADICYP, Espoo, Finland, September 26-28, 2016. 
Stoffel, R.B.; Felissia, F.E.; Silva Curvelo, A.A.; Gassa, L.M.; Area, M.C. 2014. Optimization of sequential alkaline-acid fractionation of pine sawdust for a biorefinery. Industrial Crops and Products 61: $160-168$.

Stoffel, R.; Vinholi Neves, P.; Felissia, F.E.; Pereira Ramos, L.; Gassa, L.M.; Area, M.C. 2017. Hemicellulose extraction from slash pine sawdust by steam explosion with sulfuric acid. Biomass and Bioenergy 107: 93-101.

Sun, Y.; Cheng, J. 2002. Hydrolysis of lignocellulosic materials for ethanol production: A review. Bioresource Technology 83: 1-11.

Trajano, H.L.; Engle, N.L.; Foston, M.; Ragauskas, A.J.; Tschaplinski, T.J.; Wyman, C.E. 2013. The fate of lignin during hydrothermal pretreatment. Biotechnology for Biofuels 6 (1): 1-16.

Wang, K.; Chen, J.; Sun, S.; Sun, R. 2015. Chapter 6: Steam Explosion. In PANDEY, A.; NEGI, S.; BINOD, P.; LARROCHE, C. (Eds.). Pretreatment of Biomass. Processes and Technologies: 76-104.

Wu, M.M.; Chang, K.; Gregg, D.J.; Boussaid, A.; Beatson, R.P.; Saddler, J.N. 1999. Optimization of Steam Explosion to Enhance Hemicellulose Recovery and Enzymatic Hydrolysis of Cellulose in Softwoods. Applied Biochemistry and Biotechnology 77-79: 47-54.

Yang, B.; Boussaid, A.; Mansfield, S.D.; Gregg, D.J.; Saddler, J.N. 2002. Fast and efficient alkaline peroxide treatment to enhance the enzymatic digestibility of steam-exploded softwood substrates. Biotechnology and Bioengineering 77(6): 678-684.

Zhao, X.; Cheng, K.; Liu, D. 2009. Organosolv pretreatment of lignocellulosic biomass for enzymatic hydrolysis. Applied Microbiology and Biotechnology 82: 815-827. 